\title{
CHEMICAL INVESTIGATION OF WOOD TREE SPECIES IN TEMPERATE FOREST IN EAST-NORTHERN ROMANIA
}

\author{
Ruxanda Bodîrlău, Iuliana Spiridon, and Carmen Alice Teacă*
}

\begin{abstract}
A quantitative evaluation of wood chemical components for some tree species in a forest area from east-northern Romania is presented here, through a comparative study from 1964 to 2000. Investigation upon the wood tree-rings in a Quercus robur $L$. tree species, as a dominant species, as regards its chemical composition and structure of the natural polymer constituents - cellulose and lignin - was also performed through chemical methods to separate the main wood components, FT-IR spectroscopy, and thermogravimetry. Having in view the impact of climate and external factors (such as pollutant depositions), some possible correlations between wood chemical composition and its further use can be made. The FT-IR spectra give evidence of differences in the frequency domains of $3400-2900 \mathrm{~cm}^{-1}$ and $1730-1640 \mathrm{~cm}^{-1}$, due to some interactions between the chemical groups $(\mathrm{OH}, \mathrm{C}=\mathrm{O})$. The crystallinity index of cellulose presents variations in the oak wood tree-rings. Thermogravimetry analyses show different behaviour of cellulose at thermal decomposition, as a function of radial growth and tree's height. A preliminary chemical investigation of oak wood sawdust shows a relatively high content of mineral elements (ash), compared with a previous study performed in 1964, fact that may indicate an intense drying process of the oak tree, a general phenomenon present in European forests for this species.
\end{abstract}

Keywords: Tree species, Wood chemical components, Oak wood tree-rings, FT-IR spectroscopy, TG, Thermogravimetric analysis

Contact information: Romanian Academy, "Petru Poni" Institute of Macromolecular Chemistry 41 A Gr. Ghica Voda Alley, Iasi, RO-700487, Romania; 'Corresponding author: cateaca@icmpp.ro, cateaca14@yahoo.com

\section{INTRODUCTION}

Wood represents a significant natural resource, renewable, capable of accumulating carbon by absorption of $\mathrm{CO}_{2}$ from the atmosphere. Wood anatomy influences its physical and mechanical properties, as well as its chemical reactivity (Durbak et al. 1998; Panshin and de Zeeuw 1980). Technological applications of wood can vary based on their structural differentiation among the different types of wood.

Nevertheless, the tree species may also provide significant functions other than wood production, such as soil conservation, climate stabilization, and social benefits. From an environmental perspective, wood may substitute for fossil fuels as a source of energy, for agricultural fibers for paper production, and for steel or plastics for material applications. The fibrous nature of wood strongly influences how it is used. For more effective and industrially acceptable utilization of wood, the original structure can be 
refined into the pure components, having in view its nature as a composite material, given by both chemical and physical components. The contributions of each one of them change with wood species and age, and with the climate of their areas of growing (Meshitsuka 1991).

In most species in temperate climates, the difference between wood that is formed early in a growing season and that formed later is sufficient to produce well-marked annual growth tree-rings. The age of a tree at any cross section of the trunk may be determined by counting these tree-rings (Miller 1999). In canopy forests of temperate latitudes, the radial growth of trees is influenced by a significant interaction of several factors, from which the climate and exogenous alterations (such as pollutant depositions) have a significant impact. Many European forests are predominantly composed of the pedunculate oak (Quercus robur L.) and beech (Fagus sylvatica) tree species. The relationships between the climatic variability and the radial growth of both tree species in many European regions have been widely studied (Rozas 2001).

Incidences of oak decline have occurred repeatedly during the past three centuries, as well as in the most recent decades. On the basis of historical records and dendrochronological measurements, oak decline in Central Europe has been attributed to the single or combined effects of climatic extremes (winter frost, summer drought), defoliating insects, and pathogenic fungi. Various abiotic (air pollution, nitrogen eutrophication, soil chemical stress, climatic extremes, site conditions) and biotic factors (insect defoliation, borer attack, infection by pathogenic fungi, microorganisms) and their interactions as causes of oak decline in Central Europe have been also discussed (Thomas, Blank, and Hartmann 2002).

Nevertheless, the significant impact of silvicultural practices on wood properties and the volume of juvenile wood produced is important for the forest industry (e.g. problems incurred because of juvenile wood are excessive longitudinal shrinkage, warp, and reduced strength). Due to environmental concerns, the land available for wood production has decreased. In order to meet future wood demand, more wood with target characteristics must be produced by intensive management practices and genetic improvements. The forest products industry is shifting raw materials from mature trees to short rotation plantation or juvenile stock. Compared to mature wood, juvenile wood has different properties, such as lower wood density, shorter fiber length, and higher contents of both lignin and compression wood. The last two mentioned characteristics result, for example, in higher chemical consumption during pulping and lower pulp yield.

Comparative data on the chemical components for some wood tree species from Iasi County, Romania are presented here, having in view a previous study on the native tree species performed by Cr. I. Simionescu and co-workers (Simionescu et al. 1964). The data regarding the forests from Iasi County (as climate and air quality) were also considered. The chemical characterization of pedunculate oak Quercus robur L., the dominant tree species in east-northern Romanian forest, specifically with regard to the tree-annual rings, was performed. The oak wood chemical structure, mainly the major components (cellulose, lignin), was investigated by FT-IR spectroscopy (Nelson and O’Connor 1964; Hergert 1971; Pandey 1999; Colom and Carrillo 2005). The behavior of cellulose to the thermal decomposition has been also investigated through thermogravimetry, evidencing variable properties during the tree's radial growth. 


\section{EXPERIMENTAL}

\section{Study Site}

The forests district, from which the tree species under study were harvested, is located in the Iasi county, on a gentle slope $\left(6-20^{\circ}\right)$, north-east oriented, with altitudes ranging from 30 to $500 \mathrm{~m}$. The soils are deep brown earths. European pedunculate oak is the dominant tree species in the forest canopy. Forests in the Iasi district represent an area of about $17 \%$ in the administrative area and are situated in the north of the Moldavian Central Plateau. The mean altitude for relief units in Podu-Iloaiei forestry region ranges from 190 to $230 \mathrm{~m}$ and a main east-southern exposure of the forests is present.

The forests are mainly composed of: plantations of quercinee (pedunculate oak Quercus robur L. and common-oak Quercus sessiliflora) - $26 \%$; hornbeam (Carpinus betulus) - $22 \%$; beech (Fagus sylvatica) -14\%; lime - tree (Tilia cordata) - $11 \%$; poplar (Populus alba) - $8 \%$; ash-tree (Fraxinus excelsior), sycamore maple (Acer pseudoplatanus) - $9 \%$; tree softwood species - only $2 \%$ (Iasi Forestry Direction, 1997). In Table 1, some data on the air quality are presented (Environmental report from Iasi Environmental Protection Agency 2000).

Table 1. Air Quality for the lasi Region

\begin{tabular}{|c|c|c|c|c|}
\hline $\begin{array}{l}\text { Pollutants, } \\
\text { measure unit }\end{array}$ & \multicolumn{3}{|c|}{$\begin{array}{l}\text { Pollutants' concentration } \\
\text { in the atmosphere }\end{array}$} & $\begin{array}{c}\text { Frequency of } \\
\text { overstep of the } \\
\text { admissible maximum }\end{array}$ \\
\hline $\begin{array}{l}\text { ammonia, } \mathrm{mg} / \mathrm{m}^{3} \\
\text { sedimental powders, } \mathrm{g} / \mathrm{m}^{2}\end{array}$ & \begin{tabular}{cc}
\multicolumn{2}{c}{ Maximum } \\
\multicolumn{2}{c}{ admissible } \\
daily & monthly \\
0.30 & - \\
- & 0.70
\end{tabular} & $\begin{array}{c}\text { Effective } \\
\text { maximum } \\
\\
0.642 \\
79.404\end{array}$ & $\begin{array}{c}\text { Mean } \\
\text { annual } \\
\\
0.0409 \\
18.39 \\
\end{array}$ & $\begin{array}{c}0.09 \\
40.74\end{array}$ \\
\hline
\end{tabular}

\section{Climatic Data}

A complete record of temperature and precipitation was obtained at the Iasi Territorial Meteorology Center. The climate in the harvesting area is temperatecontinental (namely hills with forests) with periods of flooding phenomena in occasional years only (e.g. 1988, 1989, 1991). Rainfall records evidence both a minimum value (in summer, from June to August) and a maximum value (in autumn-winter from October to December). The mean annual precipitation has a value of $474.4 \mathrm{~mm}$. Maximum temperature values are recorded during summer (from July to September), while minimum temperatures are observed in winter (from December to February), with a mean annual temperature of $9.6{ }^{\circ} \mathrm{C}$.

\section{Sampling and Chemical Investigation}

Dry wood is primarily composed of cellulose, lignin, hemicelluloses, and minor amounts $(5 \%$ to $10 \%)$ of extractives materials. Cellulose, the major component, constitutes up to $50 \%$ of wood substance by weight. Cellulose is a high-molecular-weight linear polymer chain which is formed by joining the anhydroglucose units into glucan chains. These anhydroglucose units are bound together by $\beta-(1,4)$-glycosidic linkages. Due to this linkage, cellobiose is established as the repeat unit for cellulose chains. The 
degree of polymerization (DP) of native cellulose is in the range of 7,000-15,000. Most of the cell wall cellulose is crystalline. Although lignin occurs in wood throughout the cell wall, it is concentrated toward the outside of the cells and between cells. Lignin is a complex three-dimensional phenylpropane polymer that forms a large molecular structure, giving mechanical strength to wood by gluing the fibers together (reinforcing agent) between the cell walls. Its structure and distribution in wood are still not fully understood (Miller 1999).

Wood represents a composite structure, given by the cell wall polymers, respectively lignin and polysaccharides - cellulose and hemicelluloses (Fengel and Wegener 1984; Pettersen 1984; Sjöstrom 1993). The combined material is known as the lignocellulosic matrix. The different amounts of these biopolymers in the cell wall polymers in wood fibers is influenced significantly by a complex of several factors, both endogenous and exogenous, and vary with wood species. Their proportions vary, but in softwoods there are normally $40-50 \%$ of cellulose, about $20 \%$ of hemicelluloses and 25 $35 \%$ of lignin. In hardwoods there are $40-50 \%$ of cellulose, $15-35 \%$ of hemicelluloses and $17-25 \%$ of lignin. There are also lot of other compounds that are found in smaller quantities, e. g. fats, resins, waxes, oils and starches. As a group they are called extractives (Rowell 1984).

Wood samples were prepared for chemical investigation and analysed by using the TAPPI standard methods, as it is described below. Wood round discs were cut from $1.30 \mathrm{~m}$ height above ground (for all wood tree species), as well as from different oak tree's height values $(1.30 \mathrm{~m} ; 8 \mathrm{~m} ; 15 \mathrm{~m})$, and let to air-dry thoroughly (TAPPI norm T $257 \mathrm{om}-85)$. The wood samples were debarked, then ground in a laboratory ball mill and sieved. For comparative study of the tree species, the fraction which passed through a $0.63 \mathrm{~mm}$ sieve was used. The oak wood flour was passed through a $0.40 \mathrm{~mm}$ sieve. All wood samples, including the fraction $>0.40 \mathrm{~mm}$ for all oak tree-rings domains (0-40 years; 40-70 years; 70-80 years), were investigated according to the analytical methods used in wood chemistry as follows:

- humidity by oven-drying at $105^{\circ} \mathrm{C}$ (TAPPI norm T 264 om-88);

- cellulose (by gravimetry), after reaction with a 1:4 v/v mixture of concentrated nitric acid and ethyl alcohol (Pettersen 1984);

- extractives by reaction with a 2:1 v/v mixture of benzene and ethyl alcohol, with a Soxhlet apparatus (TAPPI norm T 204 om-88);

- extractives by reaction with one percent sodium hydroxide solution (TAPPI norm T 212 om-88);

- extractives in hot water (TAPPI norm T 207 om-88).

The cellulose content was determined as follows: $1 \mathrm{~g}$ (oven-dried) of wood sample was placed in a $200-\mathrm{mL}$ beaker to which $5 \mathrm{~mL}$ of concentrated $\mathrm{HNO}_{3}$ and $20 \mathrm{~mL}$ of ethyl alcohol were added. The mixture was heated in a water bath and refluxed for 60 min, after that being filtered using a tared fritted disc glass thimble. The 60-min cycle was repeated for up to 4 cycles. After each succeeding hour, the wood sample was placed again in the $200-\mathrm{mL}$ beaker and fresh portions of $5 \mathrm{~mL}$ of concentrated $\mathrm{HNO}_{3}$ and $20 \mathrm{~mL}$ of ethyl alcohol were added with shaking. At the end, the reaction mixture was filtered using a tared fritted disc glass thimble, washed with hot water, and dried at $105^{\circ} \mathrm{C}$ until the crucible weight was constant, and the cellulose content was calculated. 
From the residue remaining after the Soxhlet extraction, the lignin and the holocellulose contents were determined. The lignin was determined by gravimetry after $72 \%$ sulfuric acid hydrolysis (by Klason lignin method - in accordance with the previous study of wood tree species performed in 1964, as well as by TAPPI norm T 222 om-88).

According to the Klason method, $1 \mathrm{~g}$ (oven-dried) of wood sample was placed in a $100-\mathrm{mL}$ beaker to which $15 \mathrm{~mL}$ of $72 \% \mathrm{H}_{2} \mathrm{SO}_{4}$ was added. The mixture was left at room temperature for $2 \mathrm{~h}$ with occasional stirring. The solution was then transferred to a 1-L Erlenmeyer flask, diluted with $560 \mathrm{~mL}$ of deionized water to a $\mathrm{H}_{2} \mathrm{SO}_{4}$ concentration of $3 \%$, and refluxed for $4 \mathrm{~h}$. The solution was then filtered, and the acid insoluble lignin was determined gravimetrically.

The holocellulose content (i.e. cellulose and hemicellulose) was also determined by gravimetry, after the reaction of the wood flour with sodium chlorite (Pettersen 1984). A wood sample, $5 \mathrm{~g}$ of oven-dried weight, was placed into a 500-mL Erlenmeyer flask, to which $200 \mathrm{~mL}$ of deionized water (having a temperature of $90^{\circ} \mathrm{C}$ ) was then added, followed by $10 \mathrm{~mL}$ of acetic acid and $2.5 \mathrm{~g}$ of $80 \%(\mathrm{w} / \mathrm{w}) \mathrm{NaClO}_{2}$. An optional $25-\mathrm{ml}$ Erlenmeyer flask was inverted in the neck of the reaction flask. The flask was kept in a water bath at $90^{\circ} \mathrm{C}$ for $60 \mathrm{~min}$, at which time $10 \mathrm{~mL}$ of acetic acid and $2.5 \mathrm{~g}$ of $80 \%$ (w/w) $\mathrm{NaClO}_{2}$ were added with shaking. The 60 -min cycle was repeated for up to 6 cycles. At the end, the flask was stoppered and cooled with cold water to stop the reaction. The reaction mixture was then filtered using a tared fritted disc glass thimble, washed with cold water and acetone, and dried at $105^{\circ} \mathrm{C}$ until the crucible weight was constant, and the holocellulose content was calculated.

All the results are presented relative to the dry matter content (\%DM).

The FT-IR spectroscopy (for oak wood cellulose and lignin) was performed by using the $\mathrm{KBr}$ (potassium bromide) disk method with a Digilab Fourier Transform Infrared (FTIR) spectrophotometer, Model Excalibur FTS-2000. The samples were mixed with $\mathrm{KBr}$ to form the pellets that contained $1 \%$ powdered sample. These $\mathrm{KBr}$ disks were employed for the FTIR spectroscopy studies.

The thermogravimetric (TG) and differential thermogravimetric (DTG) curves for the cellulose thermal decomposition process were recorded on a Paulik-Erdey-type derivatograph, MOM Budapest (Hungary), under the following operational conditions: heating rate was $12^{\circ} \mathrm{C} / \mathrm{min}$, temperature range $20-600^{\circ} \mathrm{C}$, sample weight $50 \mathrm{mg}$, using powdered samples in platinum crucibles, $30 \mathrm{~cm}^{3} / \mathrm{min}$ air flow. Three or four repeated readings (temperature and weight loss) were performed on the same TG curve, each of them having at least 15 points. Kinetic parameters of thermal degradation for each degradation step were determined by Coats-Redfern method (Coats and Redfern 1964), using a computer program that processed the thermogravimetry data up to $600^{\circ} \mathrm{C}$.

\section{RESULTS AND DISCUSSION}

\section{Wood Major Chemical Constituents}

For many applications a better understanding of the chemistry, properties, and performance of wood fibers is required. 
Many wood species from temperate forests have insufficient durability for the intended applications. At this moment this problem is solved partly by using biocides (containing for example: creosote, arsenic, zinc, copper, chromium, etc.) and partly by using tropical hardwoods. Since both the traditional wood preservation and the use of tropical species are under environmental and legislative pressure, the timber industries are seeking alternatives. The use of native grown species with enhanced qualities would be the ultimate solution to this problem.

Wood modification aims at altering the molecular structure of the cell wall polymers. Wood modification can change important properties of the wood, including biological durability, dimensional stability, hardness, and UV-stability by converting hydrophilic OH-groups into larger, more hydrophobic groups. Specific wood modification processes designed for the production of wood plastic composites may be developed, having in view the properties of the wood component in the composites, but also the improved interaction, e.g. by means of grafting processes.

The physical and chemical properties of wood are derived directly from the composition and morphology of the cell walls, depending on the processes of biosynthesis and assembly. Morphological and chemical characteristics of wood can be modified significantly by environmental influence. As wood biomass represents a significant source of energy and raw materials, having a remarkable potential for a continuous recovery, a comparative study on evolution of wood chemical composition for 12 different tree species from the Iasi forestry district was performed (see Table 2).

Table 2. Tree Species Considered for the Comparative Study

\begin{tabular}{|l|c|c|}
\hline \multicolumn{1}{|c|}{ Tree species } & $\begin{array}{c}\text { Tree diameter } \\
(\mathrm{m})\end{array}$ & Age (years) \\
\hline Poplar (Populus alba) & 0.35 & 18 \\
\hline Cherry-tree (Cerasus avium L ) & 0.35 & 52 \\
\hline Ash-tree (Fraxinus exce/sior L.) & 0.30 & 52 \\
\hline Hornbeam (Carpinus betulus L.) & 0.28 & 46 \\
\hline Beech (Fagus silvaticaL.) & 0.345 & 83 \\
\hline Common-oak(Quercus sessiliflora) & 0.40 & 89 \\
\hline Oak (Quercus robur L.) & 0.355 & 80 \\
\hline Lime-tree (Tilia cordata Mill.) & 0.41 & 70 \\
\hline Willow (Salix alba L.) & 0.33 & 19 \\
\hline Elm (UImus foliacea Gilib.) & 0.175 & 50 \\
\hline Ash-tree (Fraxinus excelsior L.) & 0.46 & 102 \\
\hline Common-maple (Acer campestre L.) & 0.44 & 96 \\
\hline
\end{tabular}

Comparative data (1964 and 2000) on wood chemical components for the tree species considered in our study are presented in Table 3 . The experimental data obtained from this investigation gave evidence of a significant increase in ash content for some tree species considered here (such as poplar, beech, elm, oak, ash-tree, common-oak). The mineral ash content of oak wood, obtained after $1 \mathrm{~h}$ at $650^{\circ} \mathrm{C}$ through a standard method (TAPPI norm T 211 om-85), increased from $0.14 \%$ (as obtained by Cr. I. Simionescu and co-workers in 1964) to $1.30 \%$ (in 2000). This evolution may be correlated with the trees' dryness, a phenomenon found especially for the quercinee tree species (including the pedunculate oak). 
Table 3. Wood Chemical Components for Different Romanian Tree SpeciesComparative Data (1964 and 2000)

\begin{tabular}{|c|c|c|c|c|c|c|c|c|c|c|}
\hline \multirow{3}{*}{$\begin{array}{l}\text { Wood } \\
\text { species/ } \\
\text { year }\end{array}$} & \multirow{2}{*}{\multicolumn{2}{|c|}{$\begin{array}{l}\text { Ash } \\
(\%)\end{array}$}} & \multicolumn{4}{|c|}{ Extractives in : (\%) } & \multirow{2}{*}{\multicolumn{2}{|c|}{$\begin{array}{c}\text { Cellulose } \\
(\%)\end{array}$}} & \multirow{2}{*}{\multicolumn{2}{|c|}{$\begin{array}{c}\text { Lignin } \\
(\%)\end{array}$}} \\
\hline & & & Hot & ater & $\mathrm{NaO}$ & $1 \%$ & & & & \\
\hline & 1964 & 2000 & 1964 & 2000 & 1964 & 2000 & 1964 & 2000 & 1964 & 2000 \\
\hline Poplar & 0.40 & 1.00 & 4.40 & 2.92 & 20.05 & 15.13 & 46.53 & 49.26 & 17.23 & 25.23 \\
\hline Cherry-tree & 0.30 & 0.41 & 3.64 & 3.52 & 20.79 & 16.92 & 48.66 & 46.64 & 20.98 & 18.25 \\
\hline $\begin{array}{l}\text { Ash-tree } \\
\text { (52 years) }\end{array}$ & 0.39 & 0.66 & 6.30 & 6.38 & 21.30 & 18.80 & 42.41 & 41.58 & 26.80 & 26.39 \\
\hline Hornbeam & 0.44 & 0.60 & 2.08 & 4.72 & 16.68 & 16.45 & 47.26 & 44.88 & 20.09 & 19.34 \\
\hline Beech & 0.44 & 1.36 & 1.75 & 2.19 & 16.21 & 13.15 & 46.24 & 47.66 & 23.49 & 25.53 \\
\hline Common-oak & 0.26 & 0.73 & 9.56 & 7.07 & 23.91 & 17.27 & 44.49 & 30 & 25.31 & 26.83 \\
\hline Oak & 0.14 & 1.30 & 8.12 & 7.56 & 23.80 & 18.27 & 45.08 & 79 & 23.32 & 24.82 \\
\hline Lime-tree & 0.46 & 0.78 & 2.18 & 2.26 & 17.93 & 13.12 & 52.43 & 49 & 20.67 & 21.41 \\
\hline Willow & 1.01 & 0.91 & 8.33 & 2.68 & 21.58 & 15.24 & 46.76 & 59 & 28.64 & 23.45 \\
\hline Elm & 0.68 & 1.41 & 2.45 & 3.78 & 16.76 & 15.45 & 49.63 & 49.03 & 27.78 & 26.14 \\
\hline $\begin{array}{l}\text { Ash-tree } \\
\text { (102 years) }\end{array}$ & 0.39 & 0.93 & 6.30 & 4.99 & 21.30 & 14.64 & 42.41 & 43.81 & 26.80 & 23.18 \\
\hline $\begin{array}{l}\text { Common- } \\
\text { maple }\end{array}$ & 0.62 & 0.72 & 4.28 & 3.07 & 18.35 & 10.57 & 44.48 & 49.95 & 24.56 & 21.99 \\
\hline
\end{tabular}

As regards the hot water extractives content, there is an obvious increase for beech and elm wood by $25 \%$ and $54 \%$ respectively, as follows from Table 3 . The largest values are observed for oak and common-oak, tree species characterized by significant tannins content. A decrease in the $\mathrm{NaOH} 1 \%$ extractives content is evidenced for all tree species. The major wood chemical components (cellulose, lignin) exhibit a corresponding variation, depending especially on the tree species.

A significant criterion for wood utilization in the pulp and paper industry is represented by the cellulose/lignin ratio $(\mathrm{C} / \mathrm{L}$ criterion). The estimated values both for $\mathrm{C} / \mathrm{L}_{\mathrm{K}}$ and $\mathrm{C} / \mathrm{L}_{\mathrm{TAPPI}}$ criterion for all wood samples are presented in Table 4 (fractions sampled from the wood round discs cut from $1.30 \mathrm{~m}$ height above ground and passed through a $0.63 \mathrm{~mm}$ sieve).

Table 4. $C / L_{K}$, and $C / L_{\text {Tappi }}$ Criterion Values Determined for the Tree Species

\begin{tabular}{|l|c|c|c|}
\hline \multicolumn{1}{|c|}{ Wood tree species } & $C / L_{K}(1964$ study $)$ & $C / L_{K}$ & $C / L_{\text {TAPPI }}$ \\
\hline Poplar & 2.70 & 1,95 & 1,94 \\
\hline Cherry-tree & 2.32 & 2,55 & 2,60 \\
\hline Ash-tree (52 years) & 1.58 & 1,58 & 1,67 \\
\hline Hornbeam & 2.35 & 2,32 & 2,22 \\
\hline Beech & 1.96 & 1,97 & 1,96 \\
\hline Common-oak & 1.74 & 1,57 & 1,62 \\
\hline Oak & 1.93 & 1,72 & 1,75 \\
\hline Lime-tree & 2.53 & 2,35 & 2,37 \\
\hline Willow & 1.63 & 2,16 & 2,19 \\
\hline Elm & 1.78 & 1,87 & 1,92 \\
\hline Ash-tree (102 years) & 1.58 & 1,88 & 1,87 \\
\hline Common-maple & 1.81 & 2,27 & 2,26 \\
\hline
\end{tabular}

wood sawdust samples $<0.63 \mathrm{~mm}$ 
Generally, the hardwood species show a C/L criterion value greater than 2. For some tree species presented here, this parameter has values lower than 2 .

Preliminarily, the main chemical components of the oak wood sawdust were quantified for each tree-rings domain (see Table 5), showing some differences depending on the height values from which the samples were assayed (in accordance with the previous study performed in 1964). For example, the cellulose content increases with the tree's radial growth. The extractives content both in hot water and percent sodium hydroxide solution increase with tree's height, while the cellulose content decreases. The total extractives content presents an increasing trend with tree's height, mainly for $(0-40)$ years oak wood tree-rings.

The oak tree species gave a wood with poor properties for pulping, both due to the higher extractives content given by tannins and the low cellulose content as evidenced by the minimum value for the $\mathrm{C} / \mathrm{L}$ criterion as compared with other native Romanian hardwood species.

Table 5. Chemical Components of the Oak Wood Tree-Rings

\begin{tabular}{|c|c|c|c|c|c|c|c|c|}
\hline $\begin{array}{c}\text { Oak } \\
\text { wood } \\
\text { sample } \\
\text { /annual } \\
\text { tree rings } \\
\end{array}$ & $\begin{array}{c}\text { hot } \\
\text { water }\end{array}$ & $\begin{array}{c}\mathrm{NaOH} \\
1 \% \\
\end{array}$ & $\begin{array}{l}\text { s } \\
\text { alcohol } \\
\text { benzene }\end{array}$ & $\begin{array}{c}\text { Total } \\
\text { extractives } \\
\%\end{array}$ & $\begin{array}{c}\text { Cellulose } \\
\%\end{array}$ & $\begin{array}{c}\text { Lignin } \\
\text { TAPPI } \\
\%\end{array}$ & $\begin{array}{l}\mathrm{C} / \mathrm{L} \\
\text { ratio }\end{array}$ & $\begin{array}{c}\text { Holo } \\
\text { cellulose } \\
\%\end{array}$ \\
\hline $\begin{array}{l}1.30 \mathrm{~m} \\
(0-40) \\
(40-70) \\
(70-80)\end{array}$ & $\begin{array}{l}7.91 \\
7.85 \\
4.57\end{array}$ & $\begin{array}{l}15.62 \\
18.95 \\
13.30\end{array}$ & $\begin{array}{l}4.21 \\
2.29 \\
2.89\end{array}$ & $\begin{array}{l}27.74 \\
29.09 \\
20.76\end{array}$ & $\begin{array}{l}40.03 \\
42.81 \\
44.40\end{array}$ & $\begin{array}{l}21.69 \\
23.75 \\
22.12\end{array}$ & $\begin{array}{l}1.845 \\
1.803 \\
2.007\end{array}$ & $\begin{array}{l}72.82 \\
71.57 \\
72.25\end{array}$ \\
\hline $\begin{array}{l}8 \mathrm{~m} \\
(0-40) \\
(40-70) \\
(70-80)\end{array}$ & $\begin{array}{c}9.87 \\
10.42 \\
4.61\end{array}$ & $\begin{array}{l}18.35 \\
17.33 \\
14.12\end{array}$ & $\begin{array}{l}3.12 \\
3.15 \\
2.33\end{array}$ & $\begin{array}{l}31.34 \\
30.90 \\
21.06\end{array}$ & $\begin{array}{l}42.04 \\
40.76 \\
46.97\end{array}$ & $\begin{array}{l}25.77 \\
23.82 \\
20.73\end{array}$ & $\begin{array}{l}1.631 \\
1.711 \\
2.265\end{array}$ & $\begin{array}{l}67.03 \\
58.44 \\
70.48\end{array}$ \\
\hline $\begin{array}{l}15 \mathrm{~m} \\
(0-40) \\
(40-70) \\
(70-80)\end{array}$ & $\begin{array}{l}12.38 \\
10.72 \\
5.94\end{array}$ & $\begin{array}{l}21.94 \\
19.59 \\
12.70 \\
\end{array}$ & $\begin{array}{l}4.26 \\
3.17 \\
2.73 \\
\end{array}$ & $\begin{array}{l}38.58 \\
33.48 \\
21.37 \\
\end{array}$ & $\begin{array}{l}37.73 \\
36.81 \\
40.96 \\
\end{array}$ & $\begin{array}{l}23.47 \\
24.71 \\
24.36 \\
\end{array}$ & $\begin{array}{l}1.607 \\
1.489 \\
1.681\end{array}$ & $\begin{array}{l}73.18 \\
67.92 \\
72.56 \\
\end{array}$ \\
\hline
\end{tabular}

\section{FT-IR Spectroscopy}

Fourier transform infrared (FT-IR) spectra were used to characterize differences between the oak wood tree-rings, with different positions of the absorption bands being observed. Due to the weak differences between the recorded FT-IR spectra for all wood tree-annual rings, only the data obtained for whole wood samples assayed from $1.30 \mathrm{~m}$ height above ground and passed through a $0.63 \mathrm{~mm}$ sieve (Figure 1) are presented here.

The FT-IR results provide evidence of some frequency domains, as follows: (3430-2922) $\mathrm{cm}^{-1}$ given by the $\mathrm{OH}$ and $\mathrm{CH}$ stretching vibrations $v_{\mathrm{OH}}$ and $v_{\mathrm{CH}} ; 1730 \mathrm{~cm}^{-1}$ characteristic to the $\mathrm{C}=\mathrm{O}$ stretching vibrations; and (1500-1360) $\mathrm{cm}^{-1}$ specific to the deformation vibrations of benzene rings, methylene and methyl groups $\delta_{\mathrm{CH}}, \delta_{\mathrm{CH} 2}, \delta_{\mathrm{CH} 3}$. 


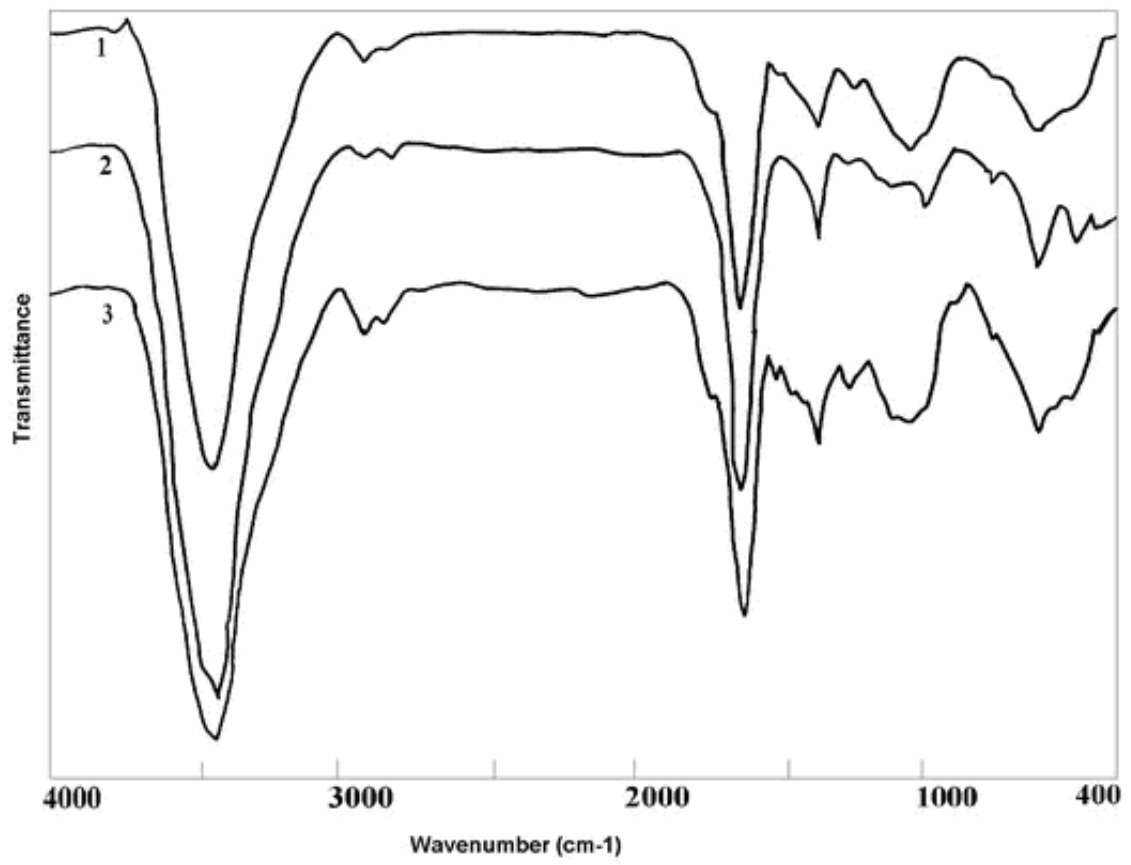

Fig. 1. FT-IR spectra recorded for the oak wood samples (height: $1.30 \mathrm{~m}$ - 1. 0-40 years; 2. 40-70 years; $3.70-80$ years).

As the tree becomes older, it is becoming more susceptible to degradation processes. Structural units that undergo various changes are functional groups located on the glucopyranose monomer in cellulose, observable in the FT-IR spectra. Carbon atoms occupying various positions in the ring (denoted as $\mathrm{C}-1, \mathrm{C}-2, \ldots \mathrm{C}-6)$ loose their identity, gradually transforming into various carbonyl groups of different degrees of freedom, namely ketonic, aldehydic, and carboxylic groups.

Next are presented the spectra for celluloses separated from wood specimens assayed from $1.30 \mathrm{~m}$ height above ground (Figure 2). Celluloses were separated from the oak wood tree-rings by the common method used in wood chemistry involving concentrated nitric acid and ethyl alcohol. The FT-IR spectra of celluloses show some differences as follows:

1. A shift to the right for spectral bands from $900 \mathrm{~cm}^{-1}$, specific to the atomic vibrations for $\mathrm{C}-1$ from the crystalline network of cellulose in the (0-40 years) wood tree-rings domain - the glucose units in cellulose are joined by $\beta$-glycoside bonds between $\mathrm{C}-1$ and $\mathrm{C}-4$ sites of adjacent sugars;

2. a shoulder at the frequency of $1730 \mathrm{~cm}^{-1}$, attributed to the spectral vibrations of $\mathrm{CH}=\mathrm{O}$ and $\mathrm{OH}$ groups during the tree's radial growth. The carbonyl band assignment allows distinguishing aldehydic and carboxyl stretching vibrations as arising around 1710 and $1740 \mathrm{~cm}^{-1}$, respectively. These give evidence to the most profound changes with time upon ageing under various conditions. 
For the (0-40 years) oak wood tree-rings, a significant asymmetry is observed for the frequency of $3400 \mathrm{~cm}^{-1}$, specific to the associated hydroxyl groups $(\mathrm{O}-\mathrm{H}$ stretching hydrogen-bonded).

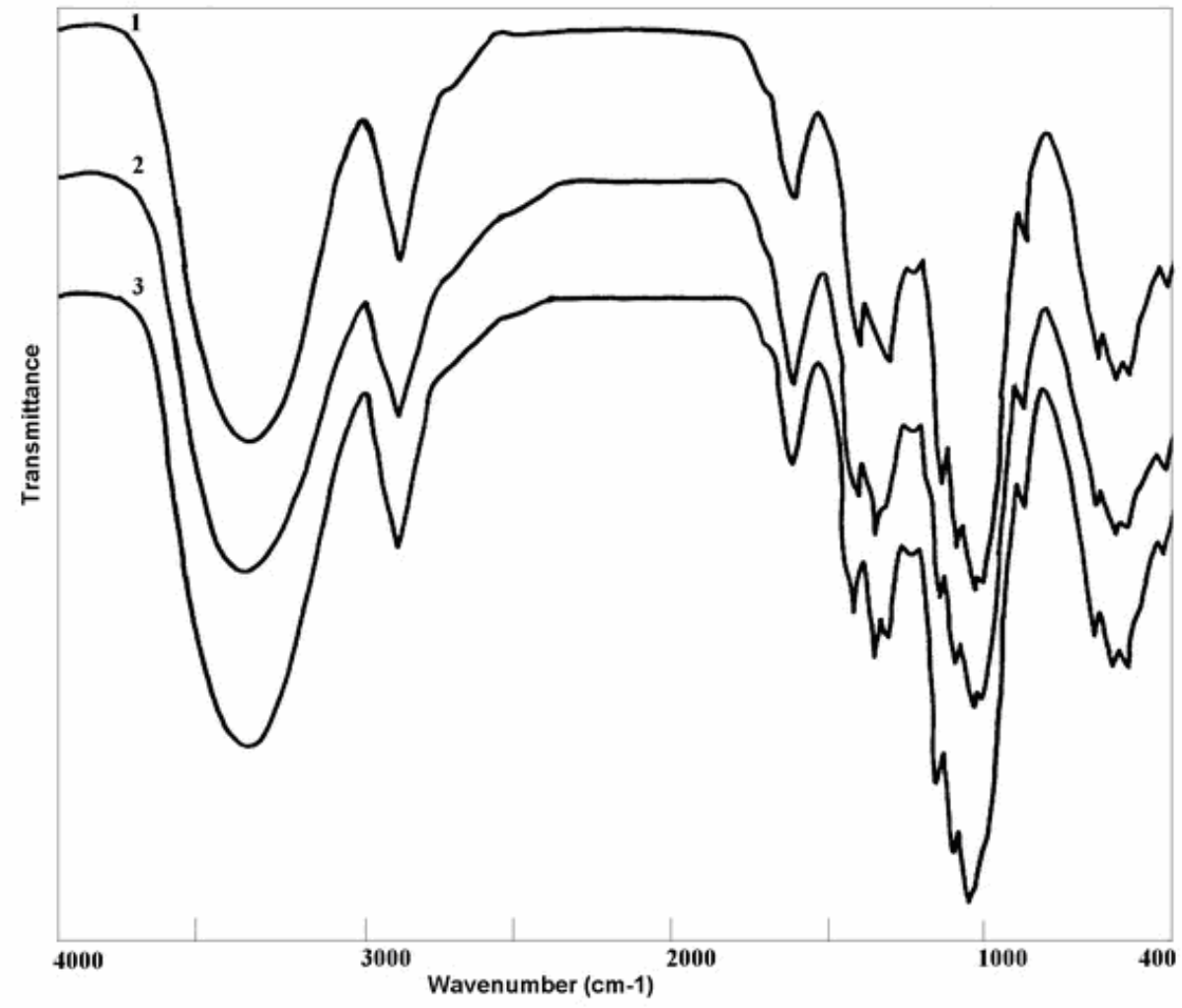

Fig. 2. FT-IR spectra for celluloses separated from the oak wood samples (height: $1.30 \mathrm{~m}-1.0$ 40 years; 2 . 40-70 years; 3 . 70-80 years).

The crystalline phase for celluloses reveals some differences depending on the oak wood tree-rings domain and height from which the wood round discs were assayed. The crystallinity index (Cr I), estimated from the FTIR spectra (Rozmarin 1984), presents a slightly decrease with the tree's growth on height (data shown in Table 6).

Table 6. Crystallinity Index for Celluloses Separated from the Oak Wood TreeRings

\begin{tabular}{|c|c|c|c|}
\hline \multicolumn{4}{|c|}{ Crystallinity index $\left(\mathrm{A}_{1371} / \mathrm{A}_{2900}\right)$} \\
\hline Annual tree -rings / height & $1.3 \mathrm{~m}$ & $8.0 \mathrm{~m}$ & $15.0 \mathrm{~m}$ \\
\hline $0-40$ years & 0.41 & 0.33 & 0.36 \\
\hline $40-70$ years & 0.31 & 0.31 & 0.29 \\
\hline $70-80$ years & 0.38 & 0.34 & 0.36 \\
\hline
\end{tabular}


The FT-IR spectra recorded for lignin isolated from the oak wood samples obtained from $1.30 \mathrm{~m}$ height above ground (Figure 3) are quite similar, excepting the intensities for the absorption bands specific to the carbonyl stretching $\left(1722 \mathrm{~cm}^{-1}\right.$ attributed to unconjugated ketone and carboxyl groups).

As it can be observed, some small frequency shifts of the absorption bands to the left (at $1031 \mathrm{~cm}^{-1}$ attributed to the aromatic $\mathrm{C}-\mathrm{H}$ in plane deformation, guaiacyl-type, and $\mathrm{C}-\mathrm{O}$ deformation, primary alcohol), respectively to the right (at $1323 \mathrm{~cm}^{-1}$ attributed to the syringyl ring breathing with $\mathrm{CO}$ stretching) are correlated with the tree's radial growth, being caused probably by the interactions between the functional groups.

The assignment of the main absorption bands from the FTIR spectra recorded for lignin is in accordance with the literature (Sakakibara 1991), showing sometimes only small variations in the band frequency (e.g., $1502 \mathrm{~cm}^{-1}$, instead of $1510 \mathrm{~cm}^{-1}$, which is a specific band for wood lignin). For the (70-80 years) oak wood tree-rings, a weak peak from a conjugated carbonyl group at $1715-1710 \mathrm{~cm}^{-1}$ is observed. This band, which may have originated from polyphenols, could be an indication of the chemical modification of lignin during the heartwood formation process. From the FTIR spectroscopy records, some parameters have been calculated, in accordance with literature data (Rozmarin 1984; Faix and Beinhoff 1988) and are presented in Table 7.

Significant decreases in both phenolic $\mathrm{OH}$ group content and S/G (syringyl/ guaiacyl) ratio value is noticed, while the $-\mathrm{C}-\mathrm{O}$ groups content increases (see Table 7). At the same time, one can observe a decreasing of the aromatic components content during the tree's radial growth.

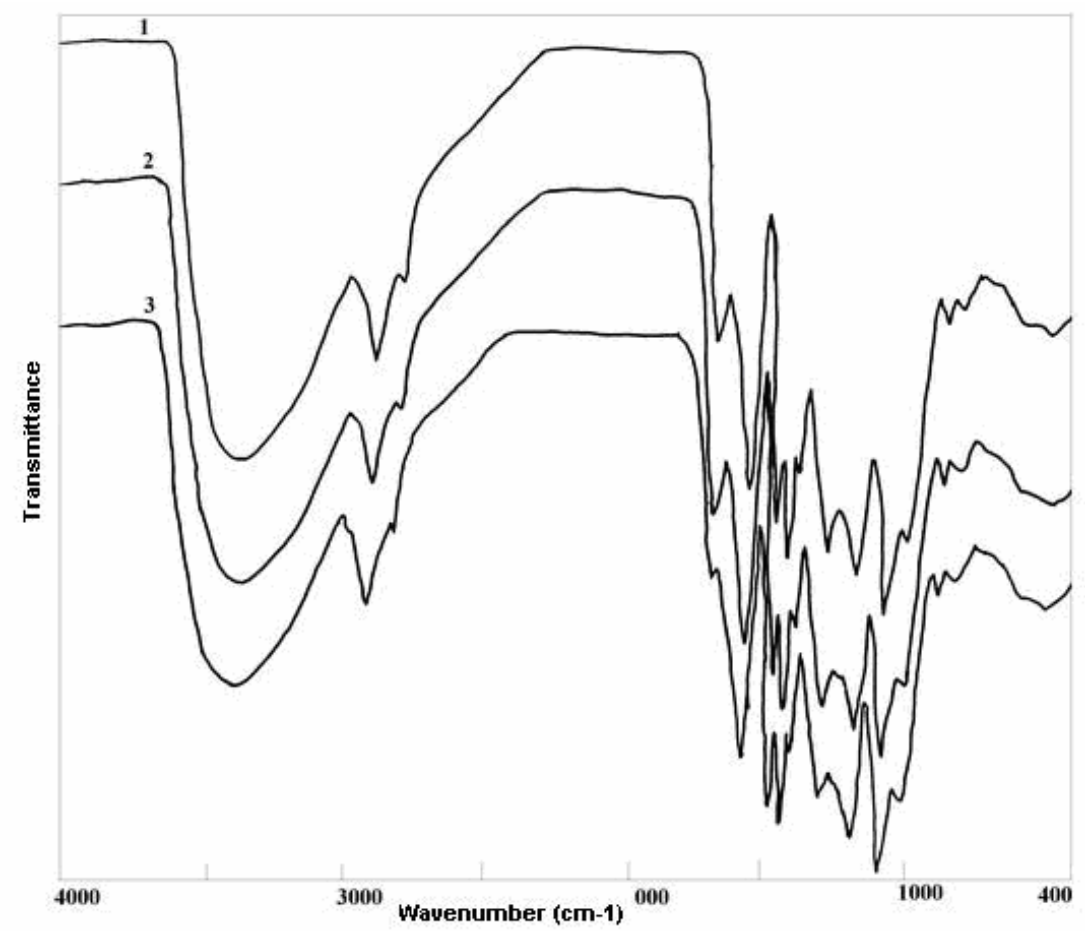

Fig. 3. FT-IR spectra for lignin separated from the oak wood samples (height: $1.30 \mathrm{~m}-$ 1. $0-40$ years; $2.40-70$ years; 3 . $70-80$ years). 
Table 7. Absorbance Ratio Representing Indication of Relative Differences in Ratio of Aliphatic to Aromatic Units and Content of Phenolic $\mathrm{OH}$ groups and $\mathrm{C}-\mathrm{O}$ Groups

\begin{tabular}{|c|c|c|c|c|}
\hline Wood sample & $\begin{array}{l}\text { Ratio of } \\
\text { aliphatic to } \\
\text { aromatic } \\
\text { signals } \\
\mathrm{A}_{2937} / \mathrm{A}_{1502}\end{array}$ & $\begin{array}{c}\text { Content of } \\
\text { phenolic } \\
\text { OH groups } \\
A_{1323} / A_{1502}\end{array}$ & $\begin{array}{c}\text { Content of } \\
\mathrm{C}-\mathrm{O} \text { groups } \\
\mathrm{A}_{1031} / \mathrm{A}_{1502}\end{array}$ & $\begin{array}{l}\text { S/G ratio } \\
\mathrm{A}_{1323} / \mathrm{A}_{1219}\end{array}$ \\
\hline 1. $3 \mathrm{~m} \quad 0-40$ years & 0.61 & 0.60 & 0.42 & 1.11 \\
\hline $40-70$ years & 0.63 & 0.72 & 0.61 & 1.03 \\
\hline $70-80$ years & 0.76 & 0.56 & 0.60 & 0.72 \\
\hline $8.0 \mathrm{~m} \quad 0-40$ years & 0.61 & 0.63 & 0.60 & 1.01 \\
\hline $40-70$ years & 0.66 & 0.60 & 0.57 & 0.96 \\
\hline $70-80$ years & 0.89 & 0.80 & 0.77 & 0.82 \\
\hline $15.0 \mathrm{~m} \quad 0-40$ years & 0.58 & 0.63 & 0.56 & 1.06 \\
\hline $40-70$ years & 0.64 & 0.61 & 0.55 & 1.05 \\
\hline $70-80$ years & 0.68 & 0.51 & 0.64 & 0.96 \\
\hline
\end{tabular}

\section{Thermogravimetry Study}

Wood thermal decomposition is considered a promising process of efficient and, in the future, economically profitable conversion of this raw material into high quality energetic and chemical products. However, designing technologies based on the pyrolysis of renewable lignocellulosic raw materials requires good knowledge of the kinetics of this process. As cellulose is the main component in wood and crops, its thermal degradation has been the subject of extensive research, which remains of interest in the perspective of reducing the energy production from fossil sources and its associated pollution. Thermal analysis was performed in order to compare the proportions of main active component in the oak wood tree-rings.

The weight loss during the thermal analysis of the wood biopolymers is characterized by three stages of degradation:

1. Up to about $150^{\circ} \mathrm{C}$ : loss of moisture content in an endothermic reaction;

2. Between 150 and about $400^{\circ} \mathrm{C}$ : decomposition of the biopolymer, with char formation and the evolution of gas (exothermic reaction);

3. Between 400 and about $500^{\circ} \mathrm{C}$ : combustion of the char (exothermic reaction).

The cellulose and hemicelluloses components of the whole biomass decompose independently of one another. Lignin decomposition is formally described by a very broad DTG peak at about $300^{\circ} \mathrm{C}$ (Antal and Varhegyi 1995; Kaloustian et al. 2001).

Thermal degradation of cellulose fits well with apparent first-order kinetics and proceeds essentially through two types of reactions (Shafizadeh 1985). At lower temperatures, between 200 and $280^{\circ} \mathrm{C}$, there is a gradual degradation that includes depolymerization, dehydration, etc. At higher temperatures, a rapid volatilization occurs, which is often accompanied by formation of 1, 6-anhydro- $\beta$-D-glucopyranose (levoglucosan). The thermogravimetric parameters for the cellulose main thermal decomposition process are presented in Table 8. From these data, one can appreciate that both the initial and final temperatures $\left(T_{i}\right.$ and $\left.T_{f}\right)$ of the main decomposition process vary significantly with the wood tree-rings. 
Table 8. Thermogravimetry Parameters for the Thermal Decomposition Process of Oak Cellulose

\begin{tabular}{|c|c|c|c|c|c|c|c|c|c|}
\hline \multirow{4}{*}{$\begin{array}{l}\text { Thermal } \\
\text { parameters }\end{array}$} & \multicolumn{9}{|c|}{ Oak wood tree-rings } \\
\hline & \multicolumn{3}{|c|}{$0-40$ years } & \multicolumn{3}{|c|}{$40-70$ years } & \multicolumn{3}{|c|}{$70-80$ years } \\
\hline & \multicolumn{9}{|c|}{ Tree's height value from which the wood samples were assayed } \\
\hline & $1.3 \mathrm{~m}$ & $8.0 \mathrm{~m}$ & $15.0 \mathrm{~m}$ & $1.3 \mathrm{~m}$ & $8.0 \mathrm{~m}$ & $15.0 \mathrm{~m}$ & $1.3 \mathrm{~m}$ & $8.0 \mathrm{~m}$ & $15.0 \mathrm{~m}$ \\
\hline $\mathrm{T}_{\mathrm{i}}{ }^{\mathrm{a}},{ }^{\circ} \mathrm{C}$ & 210 & 191 & 225 & 205 & 262 & 223 & 218 & 257 & 213 \\
\hline $\mathrm{W}_{\mathrm{Ti}}{ }^{\mathrm{b}}, \%$ & 5.8 & 6,0 & 5.5 & 6.0 & 8.2 & 7.8 & 6.5 & 6.8 & 10.5 \\
\hline $\mathrm{T}_{\max }{ }^{\mathrm{c}},{ }^{\circ} \mathrm{C}$ & 318 & 328 & 325 & 324 & 338 & 310 & 320 & 330 & 323 \\
\hline $\mathrm{W}_{\mathrm{Tmax}}{ }^{\mathrm{d}}, \%$ & 53 & 50 & 51 & 50 & 52 & 51.5 & 56 & 59 & 57 \\
\hline $\mathrm{T}_{\mathrm{f}}{ }^{\mathrm{e}},{ }^{\circ} \mathrm{C}$ & 410 & 410 & 409 & 400 & 418 & 388 & 397 & 405 & 382 \\
\hline $\mathrm{W}_{\mathrm{Tf}}^{\dagger}, \%$ & 81 & 81 & 81.5 & 79 & 82 & 77 & 78.2 & 81.5 & 82 \\
\hline $\mathrm{Ea}^{\mathrm{g}}, \mathrm{Kj} / \mathrm{mol}$ & 85.27 & 106.24 & 82.30 & 93.07 & 102.49 & 82.58 & 86.27 & 104.44 & 79.24 \\
\hline $\mathrm{n}^{1}$ & 0 & 0.8 & 0 & 0 & 0.9 & 0 & 0 & 0.8 & 0 \\
\hline
\end{tabular}

${ }^{\mathrm{a}} \mathrm{Ti}=$ initial temperature; ${ }^{\mathrm{b}} \mathrm{W}_{\mathrm{Ti}}=$ initial weight loss; ${ }^{\mathrm{c}} \mathrm{T}_{\max }=$ maximum temperature;

${ }^{\mathrm{d}} \mathrm{W}_{\mathrm{Tmax}}=$ weight loss at $\mathrm{T}_{\max } ;{ }^{\mathrm{e}} \mathrm{T}_{\mathrm{f}}=$ final temperature; ${ }^{\mathrm{f}} \mathrm{W}_{\mathrm{Tf}}=$ final weight loss; ${ }^{g} \mathrm{E}_{\mathrm{a}}=$ activation energy; ${ }^{i} \mathrm{n}=$ reaction order.

The higher values for crystallinity index ( $\mathrm{Cr}$ I) of cellulose isolated from the (0-40 years) oak wood tree-rings are in accordance with the literature data, influencing to a great extent the thermal decomposition process of this biopolymer (Kosic et al. 1973).

The activation energy ranges in the $(79.24-106.24) \mathrm{kJ} / \mathrm{mol}$ domain. Higher values for the activation energy and a first-order reaction for the degradation process are noticed for all celluloses separated from the oak wood specimens assayed from $8.0 \mathrm{~m}$ height above ground (see Table 8 ). The weight loss values calculated vary between $77 \%$ and $82 \%$ (Fig. 4-6) at the end of the main thermal decomposition process for cellulose.

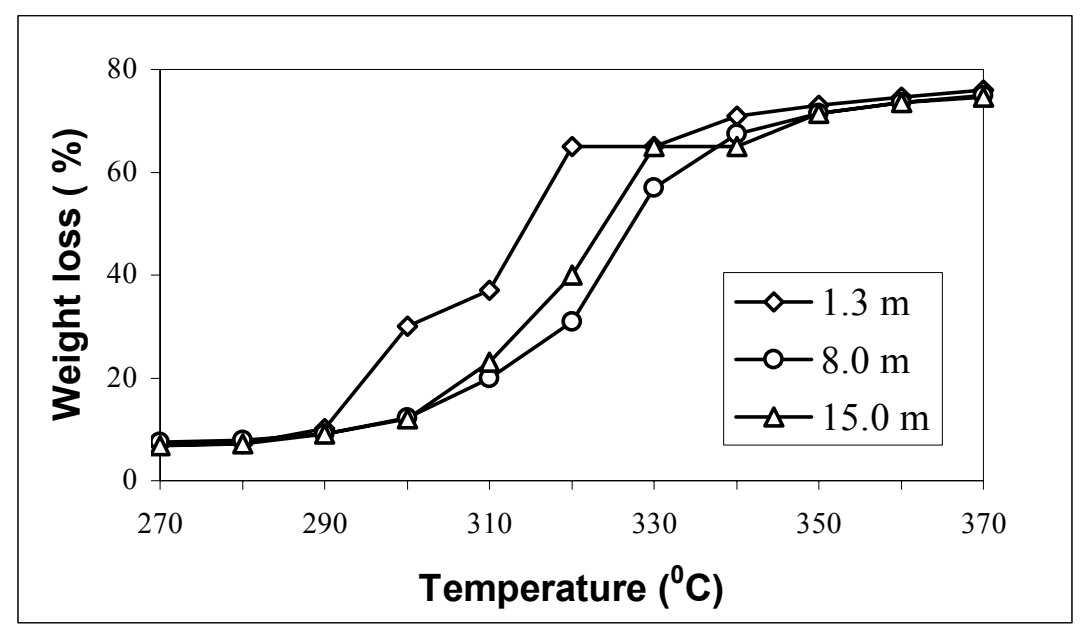

Fig. 4. Weight loss values calculated for cellulose thermal decomposition process (samples from 0-40 years oak wood tree-rings). 


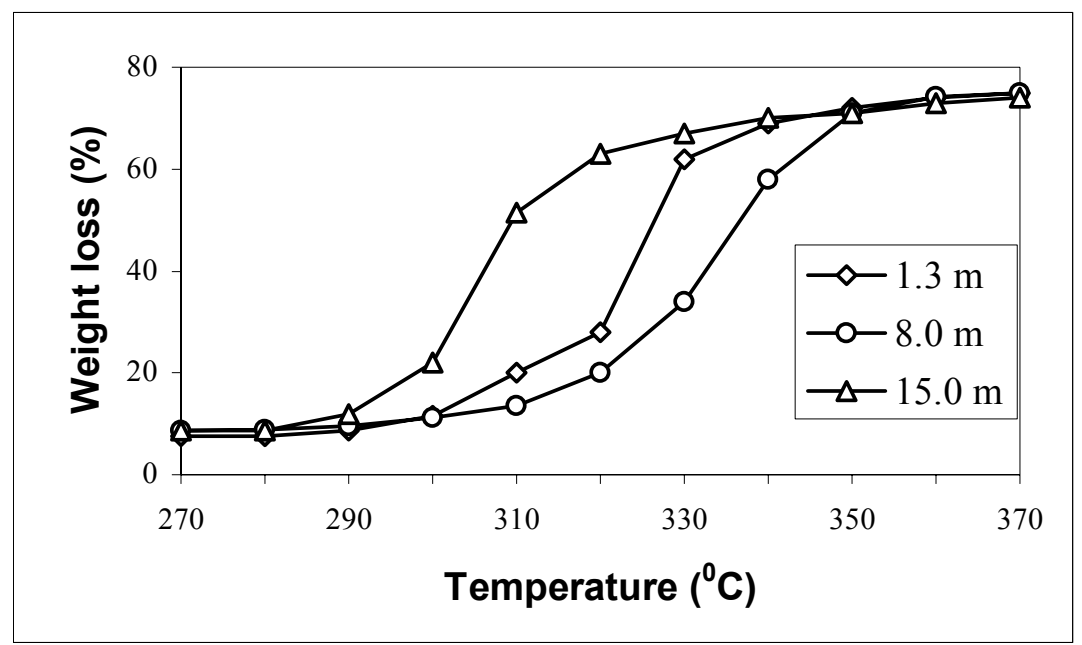

Fig. 5. Weight loss values calculated for cellulose thermal decomposition process (samples from 40-70 years oak wood tree-rings).

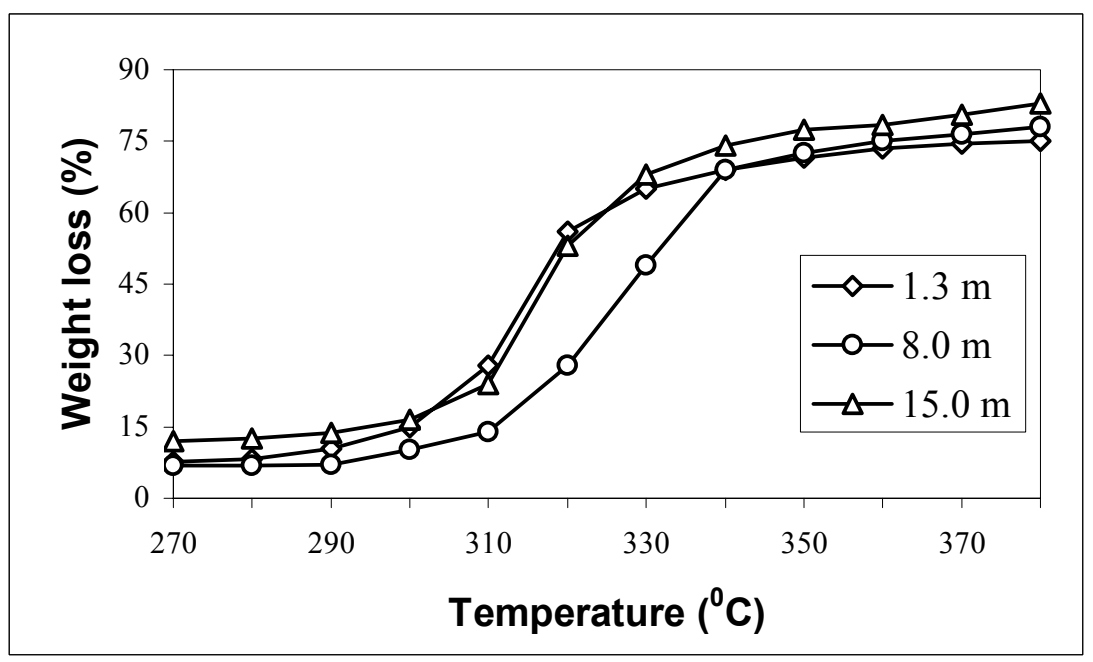

Fig. 6. Weight loss values calculated for the cellulose thermal decomposition process (samples from 70-80 years oak wood tree-rings).

All these aspects may be correlated with the structural associations of the macromolecular chains, as an immediate response to the environmental changes during the trees' growth. The thermal behavior of the wood cell wall polymers is strongly related to their content in the native vegetal biomass (Simpson and TenWolde 1999; Shafizadeh 1982). Nevertheless, the environmental perturbations have a real and huge impact on the trees' growth, the wood cell wall biopolymers - cellulose and lignin- being sensitive to any external variation.

\section{CONCLUSIONS}

1. Wood chemical components show significant variations depending on the tree species and the climate conditions (e.g. a decrease of the $\mathrm{NaOH} 1 \%$ extractives content). The 
major wood chemical components (cellulose, lignin) exhibit a corresponding variation. Differences are also noticed by comparison with the previous data on Romanian wood tree species. As general evidence, a special mention should be made on the wood ash content for all tree species which increases. This aspect can be an expression of the trees' dryness process, a fact evidenced mainly for the oak tree species.

2. The cellulose content increases during the oak tree's radial growth, depending on the tree-rings domains, and height from which the wood round discs were assayed. The cellulose/lignin ratio $(\mathrm{C} / \mathrm{L})$ values are correlated with the tree's height values $\left(\mathrm{C} / \mathrm{L}_{1.30 \mathrm{~m}}<\mathrm{C} / \mathrm{L}_{8 \mathrm{~m}}<\mathrm{C} / \mathrm{L}_{15 \mathrm{~m}}\right)$, being higher for the (70-80) tree-rings considered here.

3. The FT-IR spectra for the oak wood samples present differences correlated with the tree species features, and fluctuant environment during the tree's radial growth. Some frequency shifts for the absorption bands both to the right at the frequency of 3430 $\mathrm{cm}^{-1}$ and to the left at $1730 \mathrm{~cm}^{-1}$, are observed. These may be correlated with the interactions given by the hydroxyl groups, respectively the carbonyl groups.

4. The FT-IR spectra for celluloses show variable intensities of absorption bands in the frequency domain of $1640-1060 \mathrm{~cm}^{-1}$, for all wood samples, due to the interactions between chemical groups. The crystallinity index (Cr I) of celluloses presents a slightly decrease with the tree's growth on height.

5. The FTIR spectra recorded for the oak wood lignin are quite similar, excepting the intensities for absorption bands specific to the carbonyl groups $\left(1722 \mathrm{~cm}^{-1}\right)$. A decrease both of the phenolic $\mathrm{OH}$ groups content and $\mathrm{S} / \mathrm{G}$ (syringyl/guaiacyl) ratio value is noticed, while the $-\mathrm{C}$ - $\mathrm{O}$ groups content increases during the tree's radial growth.

6. The thermogravimetry study of celluloses separated from the oak wood samples gives evidence of a main temperature domain for the thermal decomposition process that is influenced to a great extent by the tree's growth process. Weight loss values $\left(\mathrm{W}_{\mathrm{Ti}}\right)$ corresponding to the initial temperature of the main thermal decomposition process are positively correlated with the tree's radial growth. At the end of the main thermal decomposition process, weight loss values $\left(\mathrm{W}_{\mathrm{Tf}}\right)$ of $77-82 \%$ are observed.

7. The chemical properties of wood, such as the hot water and alkali extractives contents, are strongly related to its behavior during the chemical pulping process. Significant correlations can be established between these chemical indications and the frequencies of bands given by the Fourier transform infrared spectra of a series of woods from different sites in Romania. The oak wood is not used in the Romanian pulp industry due to its specific characteristics that cause many difficulties in processing (e.g. due to the large amounts of tannins and lower $\mathrm{C} / \mathrm{L}$ ratio value). It is mainly used for furniture production.

8. This kind of methodology can be extended to some other tree species for assessing the pulpwood quality of wood from standing trees, because the measurements can be made rapidly and require only small samples. Nevertheless, this approach of the wood tree chemistry may be valuable for investigation of the chemical modification performed both on the wood and its major components (cellulose and lignin). Through this process, materials with given and special properties (e.g. thermal stability, resistance to decay, introduction of some reactive functional groups through addition of different chemicals to the hydroxyl groups of the wood material for further grafting synthetic polymers in order to obtain composites) may be obtained. 


\section{ACKNOWLEDGEMENTS}

The authors are grateful for the support of the Research and Technology Ministry of Romania - National Agency for Science, Technology and Innovation, Grant No. 5052/1999-2001.

\section{REFERENCES CITED}

Antal, M. J., and Varhegyi, G. (1995). "Cellulose pyrolysis kinetics. The current state of Knowledge," Ind. Eng. Chem. Res. 34, 703-717.

Coats, A. W., and Redfern, J. P. (1964). "Kinetic parameters from thermogravimetric Data," Nature 201, 68-69.

Colom, X., and Carrillo, F. (2005). "Comparative study of wood samples of the northern area of Catalonia by FTIR," J. Wood Chem. Technol. 25/1-2, 1-11.

Durbak, I., Green, D. W., Highley, T.L., Howard, J. L., McKeever, D.B., Miller, R.B., Pettersen, R.C., Rowell, R.M., Simpson, W.T., Skog, K.E., White, R.H., Winandy, J. E., and Zerbe, J. I. (1998). Wood, Kirk-Othmer Encyclopedia of Chemical Technology, R. E. Kirk-Othmer, F. Kroschwitz, M. Howe-Grant, eds., volume $25,4^{\text {th }}$ ed., Wiley, New York.

Faix, O., and Beinhoff, O. (1988). "FTIR spectra of milled wood lignins and lignin polymer models (DHP's) with enhanced resolution obtained by deconvolution," $J$. Wood. Chem. Technol. 8/4, 505-522.

Fengel, D., and Wegener, G. (1984). Wood Chemistry, Ultrastructure, Reactions, de Gruyter Verlag, Berlin, Germany.

Hergert, H.L. (1971). Infrared Spectra, Lignins, K.V. Sarkanen, C.H. Ludwig, eds., Wiley-Interscience, New York.

Kaloustian, J., Pauli, A. M., and Pastor, J. (2001). "Kinetic study of the thermal decomposition of biopolymers extracted from various plants," J. Therm. Anal. Cal. 63/1, 7-20.

Kosik, M., Reiser, V., and Michalic, J. (1973). "Thermal and thermooxydation degradation of cellulose. Effect of crystallinity," Papira Celulosa 28 /7-8, 29-31.

Meshitsuka, G. (1991). Utilization of Wood and Cellulose for Chemicals and Energy, Wood and Cellulosic Chemistry, D. S. Hon, N. Shiraishi, eds., Marcel Dekker Inc., New York.

Miller, R. B. (1999). Structure of Wood, Gen. Technical Report FPL-GTR-113 Wood Handbook-Wood as an Engineering Material, U. S. Department of Agriculture, Forest Service, Forest Products Laboratory, Madison, WI, USA, (http://www.fpl.fs.fed.us/documents/).

Nelson, M. L., and O'Connor, R. T. (1964). "Relation of certain infrared bands to cellulose crystallinity and crystal lattice type. Part II. A new infrared ratio for estimation of crystallinity in cellulose I and II," J. Appl. Polym. Sci. 8, 1325-1341.

Pandey, K. (1999). "A study of chemical structure of soft and hardwood and wood polymer by FTIR spectroscopy," J. Appl. Polym. Sci. 71, 1969-1975.

Panshin, A. J., and De Zeeuw, C. (1980). Textbook of Wood Technology: Structure, Identification, Uses and Properties of the Commercial Woods of the United States 
and Canada, $4^{\text {th }}$ ed., McGraw-Hill, New York.

Pettersen, R. (1984). Chemical Composition of Wood, The Chemistry of Solid Woods, R. M. Rowell, ed., Advances in Chemistry Series 207, American Chemical Society, Washington D.C.

Rozas, V. (2001). "Detecting the impact of climate and disturbances on tree-rings of Fagus sylvatica L. and Quercus robur L. in a lowland forest in Cantabria, northern Spain," Ann. For. Sci. 58, 237-251.

Rozmarin, Gh. (1984). Macromolecular Basis of Wood Chemistry, Technical Publishing House, Bucharest, Romania.

Rowell, R. M. (1984). The Chemistry of Solid Wood, American Chemical Society, Washington D.C.

Sakakibara, A. (1991). Chemistry of Lignin, Wood and Cellulosic Chemistry, N. S. Hon, N. Shiraishi, eds., Marcel Dekker Inc., New York.

Shafizadeh, F. (1982). "Introduction to pyrolysis of biomass," J. Anal. Appl. Pyrolysis 3, 283-305.

Shafizadeh, F. (1985). Thermal Degradation of Cellulose, Cellulose Chemistry and Its Applications, T. P. Nevell, S. H. Zeronian, eds., Ellis Horwood, Chichester, UK.

Simionescu, Cr. I., Grigoras, M., and Asandei, A. (1964). Wood Chemistry of Tree Species from Romania, Romanian Academy Publishing House, Bucharest, Romania.

Simpson, W., and TenWolde, A. (1999). Physical Properties and Moisture Relations of Wood, Gen. Technical Report FPL-GTR-113 Wood Handbook - Wood as an Engineering Material, U. S. Department of Agriculture, Forest Service, Forest Products Laboratory, Madison, WI, USA, (http://www.fpl.fs.fed.us/documents/).

Sjöstrom, E. (1993).Wood Chemistry: Fundamentals and Applications, $2^{\text {nd }}$ ed., Academic Press, New York.

TAPPI (US Technical Association of Pulp and Paper Industry): Sampling and preparing wood for analysis, norm T 257 om-85, 1985.

TAPPI (US Technical Association of Pulp and Paper Industry): Ash in wood, pulp, paper, and paperboard, norm T 211 om-85, 1985.

TAPPI (US Technical Association of Pulp and Paper Industry): Preparation of wood for chemical analysis, norm T 264 om-88, 1988.

TAPPI (US Technical Association of Pulp and Paper Industry): Wood extractives in ethanol-benzene mixture, norm T 204 om-88, 1988.

TAPPI (US Technical Association of Pulp and Paper Industry): One percent sodium hydroxide solubility of wood and pulp, norm T 212 om-88, 1988.

TAPPI (US Technical Association of Pulp and Paper Industry): Water solubility of wood and pulp, norm T 207 om- 88, 1988.

TAPPI (US Technical Association of Pulp and Paper Industry): Acid insoluble lignin in wood and pulp, norm T 222 om-88, 1988.

Thomas, F. M., Blank, R., and Hartmann, G. (2002). "Abiotic and biotic factors and their interactions as causes of oak decline in Central Europe," Forest Pathology 32/4-5, 277-307.

Article submitted: Nov. 29, 2006; First round review completed: Jan. 3, 2007; Revision accepted: Jan. 22, 2007; Article published Jan. 24, 2007 